\title{
Foundations of Value Disorientation in Africa: Example of the Nigerian Education System
}

\author{
Stephen Asombu Saa-Aondo \\ Department of Mass Communication, Bayero University, Kano, Nigeria
}

Email address:

saasteven@yahoo.com

\section{To cite this article:}

Stephen Asombu Saa-Aondo. Foundations of Value Disorientation in Africa: Example of the Nigerian Education System. Humanities and Social Sciences. Special Issue: Digital Media and Cultural Globalisation: The Fate of African Value System. Vol. 7, No. 6, 2019 , pp. $209-213$. doi: $10.11648 /$ j.hss.20190706.14

Received: August 31, 2019; Accepted: October 15, 2019; Published: December 25, 2019

\begin{abstract}
Human personality is a product of cultural ideologies transmitted via institutions of socialisation - family, schools, religion, and the mass media. The school system is responsible for secondary socialisation of citizens after the family. The major obligation is the purposeful creation and strengthening of personality, to give the citizens proper formation so that they can integrate socially and take up responsibilities in the various facts of the society. The success or otherwise of this obligation depends on the values that dominate the learning environment of the citizens. Using the tenets of Skinner's learning theory of personality, this study seeks to establish a relationship between the prevalent environment of learning and the high rate of value disorientation in Nigeria. The paper combines ethnographic observation and conceptual review methods. Some of the factors of value disorientation identified include, discordant religious doctrines in schools, marketing of schools with examination fraud, and environment of injustice and human rights abuse. The study recommends that government should separate religious education from formal education so that Nigerian schools will no longer be used as avenues of inculcating discordant religious beliefs and doctrines; and that the national and state houses of assembly should make legislations that will empower students to demand for justice when their rights are violated.
\end{abstract}

Keywords: Value Disorientation, Value Education, Nigerian Education System, Nigerian Schools

\section{Introduction}

Human personality is a product of cultural ideologies transmitted via institutions of socialisation, the school being one of them. Apart from informal socialisation that takes place in the school environment, education itself is expected to function as a value orientation process. The emphasis is first on values, then sharpening of potentials. This partly explains the common clause used by institutions of learning at graduation ceremonies of students where the faculty representative would presents the graduands as being found worthy for graduation "both in character and learning."

Education, moreover, is the foundation of society (common knowledge), and also the foundation of human and national development, as evident also in the global push for formal education of children, being part of world development policies such as the Millennium Development Goals (MDGs) and currently the Sustainable Development Goals (SDGs) [1]. Therefore, it suffices to trace the failure of good value system in Nigerian society to education system.

This study seeks to establish the linkage between the environment of formal education and the state of value disorientation in the Nigerian society, which is characterised by high rate of intolerance, injustice, violence, bribery and other forms of corruption.

The study combines ethnographic observation and conceptual review methods, the observation being participant, based on personal and vicarious experiences of the author as a student and as a lecturer in private polytechnic.

\section{Problem Statement}

Nigerian education system is riddled with many abnormalities, which have apparently become a culture and defined standard of academic business. Sociologically, one can best describe the type of formal education in Nigeria as discordant socialisation, which in the words of Crisogen, does not fall within the provisions of moral ideals [2]. 
Beyond ethnographic experience, several research studies, such as Odia and Omofonmwan [3], Egbefo [4], Umo [5], Oladele, O. O and Oladele [6] and Mbagwu [7] have documented myriads of antisocial, corrupt and unethical behaviours, which have become normal in institutions of learning in Nigeria.

Research however, has not sufficiently addressed the linkage between these antisocial, unethical and corrupt behaviours in education and the moral decay in society.

Consequently, this study seeks to bridge that gap by determining what relationship exists between the ugly experiences in schools and the high rate of value disorientation in Nigeria.

\section{Theoretical Background}

This study builds its argument on "the learning theory of personality" by Burrhus Frederic Skinner - a behaviourist theory, which suggests that personality is no more (or less) than a collection of learned behaviour patterns [8].

According to Sincero [9], the learning theory of personality proposes that the patterns of human behaviour are determined by individual learning experience; and that these patterns of behaviour are learned either directly (through positive reinforcement of reward for good behaviour or negative reinforcement as a punishment for bad behaviour) or indirectly (through observational learning or modelling).

Skinner's theory is relevant to this study given its emphasis on learning experiences and human behaviour. The tenets of the theory serve as guide to the reader in trying to understand how the prevailing moral environment in places of learning determines the personality of students or school children.

\section{Discussion}

The school system is fundamentally responsible for secondary socialisation of citizens, saddled with the task of value orientation - formation of citizens so that they can socially integrate and take up responsibilities in the various facets of their society. According to Pescaru [10], this socialisation process can only prove to be efficient when through its deliberate efforts the "individual's ability is developed to manage himself, to discern between good and evil, to know how to choose between the moral attitudes that are assessed by society negatively and those which allow for adequate social cohabitation." This means, a society's educational system can rightly be said to have failed if there is widespread antisocial behaviours, official misconducts, insecurity, and other corrupt tendencies.

As a concept, Crisogen [2] clarifies secondary socialisation as:

The period in which a child begins to interact strongly with other social environments than the family...it continues throughout the entire life of the individual, with the purposeful creation and strengthening of personality... it is identified with formal education. (p. 332)

This conceptualisation points out several important things about secondary socialisation. It links formal education with socialisation process of a child. In other words, secondary socialisation is formal education. Also, it provides the basic characteristic of secondary socialisation - $a$ deliberate (purposeful) policy of "creating and strengthening of personality." That is, deliberate policies aimed to inculcate (create) in children the "rules of behaviour, values or norms" that were not learned (during primary socialisation); to reinforce (reward) the good personality that was learned; discourage (punish) the bad personality, and realign (strengthen) misplaced personality.

The quotation implies that for a formal education system to achieve the aim of socialisation of children, it must make, implement, and closely monitor deliberate policies towards value orientation of children - inculcation and strengthening of personality. This is one of the major concerns in the Nigeria education system.

\subsection{Lack of Proper Value Education}

Educational efforts in Nigeria are largely focused on sharpening skills without commensurate efforts at value formation. While the national policy on education provides the national educational goals, in part, as "the inculcation of the right type of values and attitudes for the survival of the individual and the Nigerian society" [11], schools at all levels, including government owned, have not invested reasonably in value education apart from introduction of few courses on morality and religious education, which are taught as part of "the training of the mind in the understanding of the world around" and not for shaping the personality of students [11].

Educational budgets in the country are exhausted on acquisition of facilities and equipment. Nigerian schools only punish misconduct of students by canning or labour (at primary and secondary level), and rustication, carryover or spill-over of courses (at the tertiary level). There are no policies or projects on ground for proper value orientation of school children by any stakeholder in the education sector.

Various trade unions exist such as the Academic Staff Union of Universities (ASUU), Nigerian Union of Teachers (at the secondary and primary school levels), Academic Staff Union of Polytechnics (ASUP), etc who have been campaigning for improved standard of public schools, however, their demands are basically related to funding of facilities, equipment and staff welfare. None of these unions have a deliberate policy to monitor and ensure an academic environment that creates and strengthens civic personality of students. Rather, the system is overwhelmed with issues of educator misconducts, injustice, sabotage, disrespect, research misconducts and examination misbehaviours.

Application of the tenets of Skinner's "learning theory of personality" to the moral environment of formal education in Nigeria gives one a clear picture of the significant extent of contribution of educational system to the alarming state of moral decay in the society. 


\subsection{Discordant Religious Doctrines in Schools}

Nigerian educational system has confused value education with religious education. The introduction of religious education in the school curricula and the subsequent involvement of religious organisations in the ownership and management of schools has also created serious problem for value orientation of children in Nigeria.

Strategically, religious education is concerned with teaching of beliefs or doctrines. These beliefs and doctrines are not universally acceptable unlike educational values of integrity, which according to the International Centre for Academic Integrity (ICAI) [12] include honesty, trust, fairness, respect, responsibility and courage. Even within the same religion, several denominations exist that represent different beliefs and doctrines.

Morally wise, there is high level of religious bigotry that does not augur good value formation of children. The two main religions in Nigeria, Christianity and Islam, have been intolerant of each other over decades, evident in incessant religious crises, which often result to dozens of deaths.

Within each of these religions also, there are several denominations, which are antagonistic among themselves. In Islam, Nigerian Taliban, the Mohammed Ali-led group of radical Islamist youth who worshipped at the Alhaji Muhammadu Ndimi Mosque in Maiduguri, became intolerant of Islamic establishment and embarked on hijra (a withdrawal along the lines of the Prophet Muhammad's withdrawal from Mecca to Medina). The move that metamorphosed into the bloodthirsty Boko haram [13].

In Christianity too, many of the denominations are intolerant of others. For example, the NKST, which is most popular in Benue State, with headquarters at Mkar - Gboko, as well as the body of churches called Pentecostals have consistently promoted religious bigotry by discouraging, or even forbidding active participation of their members in activities involving selected denominations, particularly the Roman Catholic Church. For instance, among worshipers of NKST denomination, it is a sanctionable offence to give out a daughter in marriage to a member of the Roman Catholic denomination even though both denominations subscribe to Christian Association of Nigeria (CAN).

The crux of the issue is that with the introduction of religious education in the school curricula, and the involvement of religious groups in the ownership and operation of schools, the prevalent bigotry among discordant religious believers have become a huge challenge to value formation in formal education. Rather than mould values of integrity in school children, Nigerian schools have become avenues for inculcating discordant religious beliefs and doctrines. Schools owned by religious bodies tend to focus on teaching children their religious beliefs, which do not conform to values of integrity, and are also capable of promoting intolerance among citizens.

Umo [5] (p.104) also writes in this line of thought that "the Muslim education, (the Qur'anic schools), the Almajiri, the Church and State as stakeholders in the educational system separately or jointly, (have) created lots of tension, conflicts and complexities in the education, social, economic and political sectors."

\subsection{Marketing Schools with Examination Fraud}

Almost every Nigerian child who finished from secondary school in the last decade, or a parent whose child finished from secondary school within the last decade, especially those who sat for their Senior School Certificate Examinations (SSCE) in rural and semi-urban areas, are familiar with the concept "understanding fee." This concept describes the sum of money taxed examination candidates (voluntary though) and duly collected by the school management during registration for such examinations as (WAEC and NECO). The fee is meant for bribing external invigilators, so that candidates can freely utilise their hired mercenaries and or prepared materials during examinations.

Part of the usual arrangement is that once the so called understanding fee is collected, the school management makes arrangement for a convenient room and competent hands in each of the subjects. While question papers are distributed to candidates in the hall, one question paper is sneaked out to the "prepared room." Depending on the agreement with the external invigilator and the extent of compliance by candidates, the prepared answers are either copied on chalk boards for candidates, or duplicated and shared among those who paid.

At the end, those who refused to pay the so called understanding fee are looked down upon as being unserious especially if their performance does not produce good results. This way, the culture of cheating or deceit is enshrined in school children. By personal experience, they know that honesty does not pay, cheating is the way to get what they want.

The reason behind this unfortunate situation is to market the institutions. The idea is that parents will want to patronise schools that consistently record good performances in external examinations, which also means, more school fees for the administrators or proprietors. However, as Crisogen [2] explains, and as the learning theory of personality teaches, in such a learning environment, a dishonest personality is purposefully created and or strengthened, which will manifest throughout the professional life of the graduate. In the same vein, Emaikwu [14] attributes the culture of fraud among youths in Nigeria to the calamity of examination malpractice.

\subsection{Environment of Injustice and Human Rights Abuse}

The environment of formal education in Nigeria in recent time, particularly at the tertiary level can be compared to that of a jungle where survival is said to be of the fittest. There are no fundamental human rights for Nigerian students. Once you become a student in Nigeria, you have apparently willed your human rights to your school authority and to your lecturers. The lecturer is the king of the jungle who does the undone.

The justice system in educational institutions does not provide opportunity for students to demand for justice when their rights 
are violated. Also, there are no educational laws that empower students to seek redress for injustice against them. This situation has encouraged all manners of misconducts against students especially in the tertiary institutions.

One of the common pieces of advice a new student receives on campus is "learn to relate well with your teachers." The implication is that success largely depends on understanding between lecturers and students, not necessary on academic performance; and freedom from trouble does not mean strict observance of rules and regulations. It depends on how well one relates with educators.

The media in Nigeria is undated with unfortunate events that characterised the experiences of students in the country including injustice, disrespect, sabotage, irresponsibility and human rights violation. These include stories of graduates who cannot read or write, for example Akinyemi [15], Aluko [16] and Omonigho [17]. There are also stories of public office holders or civil servants who cannot prove their certificates, example, Peter [18] and Sarara Reporters [19]. Others are stories of students who have committed suicide out of depression, example Azeez [20], Online Punch [21], Emmanson [22], and Abia [23]. Also, there are stories of scandals of sex-for-marks transactions between lecturers and students, example Kabir [24], Nseyen [25], and Egbejule [26].

According to the learning theory of personality, which the study anchored, an individual's personality is a product of his or her learning experience. Therefore, given the experience in the environment of formal education in Nigeria, it suffices to logically conclude that just as education is said to be the foundation of society, the Nigerian educational system is rightly the foundation of value disorientation in the country.

\section{Conclusion}

The dominant character of a society communicates the state of educational system of the society; and the problems of a given society can rightly be traced to educational system of the society given the centrality of the foundation in determining the strength of a building. This study attempts a careful observation and discussion of the Nigerian education system in relation to the state of moral decay in society based on the teachings of Skinner's learning theory of personality.

Several experiences of value disorientation have been identified in the Nigerian education system, including lack of proper value education, discordant religious doctrines in schools, marketing of schools with examination fraud, and environment of injustice and human rights abuse.

The paper concludes that the prevailing environment of formal education in Nigeria has a significant contribution to the high rate of value disorientation in the society.

\section{Recommendations}

Based on the issues identified and discussed as being prevalent in Nigerian schools, the following recommendations were made: (i) Governments at all levels (since education in Nigeria is a concurrent responsibility) should remove religious education from the curricula of formal education. The religious institution is another agent of socialisation just like schools. The teaching of religious doctrines and beliefs should therefore, be left into the hands of religious houses. So that, Nigerian schools will no longer be used as avenue for spreading discordant religious beliefs and doctrines.

(ii) Since value orientation is largely achieved through learning experiences, the ministry of education, through the regulatory agencies in the education sector such as the Nigeria Universities Commission (NUC), the National Board of Technical Education, State Universal Education Boards (SUBEBs) and others, should ensure that all schools in Nigeria have encompassing academic integrity policies that are properly planed, implemented, monitored, evaluated and updated by a designated unit for the purpose. This will ensure an atmosphere of integrity in their school environments - environment where in the conduct of examination and all other academic transactions, every constituent member is committed, even in the face of adversity, to the fundamental and universal values as defined by the International Centre for Academic Integrity: honesty, trust, fairness, respect, responsibility and courage.

(iii) The national assembly or State Houses of Assembly should make legislations that will empower students to demand for justice or seek redress from courts of law and justice in events of violation of their rights.

(iv) Nigerians who are concerned with integrity should form nongovernmental organisations to mount surveillance in schools and in government ministries, agencies and departments to identify and fish out all corrupt tendencies in the education system.

\section{References}

[1] United Nations. (2017). The Sustainable Development Goals Report. Retrieved from https://sdgactioncampaign.org/wp-content/uploads/2017/07/T heSustainableDevelopmentGoalsReport 2017.pdf

[2] Crisogen, D. T. (2015). Types of socialization and their importance in understanding the phenomena of socialization. European Journal of Social Sciences, 2 (4), pp. 331-336.

[3] Odia, L. O. \& Omofonmwan, S. I. (2007). Educational system in Nigeria problems and prospects. Journal of Social Science, 14 (1), pp. 81-86.

[4] Egbefo, D. O. (2012). Corruption in the Nigerian educational system: it's implication in manpower and national development in the age of globalization. Journal of Arts and Education, 6 (2), pp. 149-266.

[5] Umo, U. A. (2014). Forms and sources of conflict in Nigerian educational system: the search for Nigerian Psyche. Global journal of educational research 13, pp. 101-108. DOI: http://dx.doi.org/10.4314/gjer.v13i2.6. 
[6] Oladele, O. O. \& Oladele, I. T. (2016). Depression and suicidal ideation among college students with and without learning disabilities in Nigeria. The European Journal of Social and Behavioural Sciences, EJSBS XVI, pp. 2084-2100. http://dx.doi.org/10.15405/ejsbs.187

[7] Mbagwu, J. U. (2018). Ethical issues in Nigerian education a philosophical rejoinder. International Journal of Scientific Research in Education, 11 (3), 357-371.

[8] Aishwarya, S. (n. d). Learning Theory by B. F. Skinner. Retrieved from http://www.psychologydiscussion.net/learning/learning-theory /learning-theory-by-b-f-skinner/1928

[9] Sincero, S. M. (2012). Behaviourist Theories of Personality. Retrieved from Explorable. com: https://explorable.com/behaviourist-theories-of-personality

[10] [10 Pescaru, M. (2019). The importance of the socialization process for the integration of the child in the society. Available on https://www.researchgate.net/publication/330076266.

[11] Federal Republic of Nigeria (2004). National Policy on Education, (4 ${ }^{\text {th }}$ Edition). Lagos: Nigerian Educational Research and Development Council (NERDC) Press.

[12] International Centre for Academic Integrity (2013). The Fundamental Values of Academic Integrity, (Second Edition). Clemson University: International Center for Academic Integrity.

[13] United States Institute of Peace (2012). What is Boko Haram? Special Report. Available on https://www.usip.org/publications/2012/05/what-boko-haram

[14] Emaikwu, S. O. (2012). Assessing the impact of examination malpractice on the measurement of ability in Nigeria. International Journal of Social Sciences and Education, 2 (4), pp.748-757.

[15] Akinyemi, A. (2018). Education disaster as illiterate graduates are reported by NYSC. Retrieved from https://www.inigerian.com/education-disaster-as-illiterate-grad uates-are-reported-by-nysc/

[16] Aluko, O. (2019). Some graduates can't recite English alphabet-NYSC. The Punch. Retrieved https://punchng.com/some-graduates-cant-recite-english-alpha bet-nysc/

[17] Omonigho, M. (2019). Most Nigerian graduates can't spell their names-Varsity Don. Retrieved from https://dailypost.ng/2019/05/12/nigerian-graduates-cant-spellnames-varsity-don/

[18] Peter, A. (2019). Many Nigerian civil servants parade fake certificates-Don. Retrieved from https://punchng.com/many-nigerian-civil-servants-parade-fake -certificates

[19] SaharaReporters (2019). UNCOVERED: 769 Civil Servants Working With 'Fake And Forged Certificates' In Osun. Retrieved from http://saharareporters.com/2019/04/19/uncovered-769-civil-se rvants-working-fake-and-forged-certificates-osun

[20] Azeez, B. (2018). Unilorin student commits suicide over failure of project. Retrieved from https://tribuneonlineng.com/unilorin-student-commits-suicideover-failure-of-project/

[21] The Punch (2019). Another final-year UNN student commits suicide. Retrieved from https://punchng.com/another-final-year-unn-student-commitssuicide/

[22] Emmanson, J. (2019). Another UNIBEN Final Year Student Commits Suicide. Retrieved from https://leadership.ng/2019/07/15/another-uniben-final-year-stu dent-commits-suicide/

[23] Abia, U. (2019). OAU: Final year student commits suicide. Retrieved from https://firstreportsonline.com/oau-final-year-student-commitssuicide/

[24] Kabir, A. (2019). Sex-for-mark Scandal: One year after, UNILAG keeps mum over allegation against professor. Retrieved from https://www.premiumtimesng.com/news/top-news/333139-sex -for-mark-scandal-one-year-after-unilag-keeps-mum-over-alle gation-against-professor.html

[25] Nseyen, N. (2019). Sex-for-marks: Ekiti State University speaks on scandal involving its lecturer, student. Retrieved from https://dailypost.ng/2019/06/15/sex-marks-ekiti-state-universit y-speaks-scandal-involving-lecturer-student/

[26] Egbejule, M. (2019). ASUU must show neutrality in sex-for-marks scandals-AAU VC. Retrieved from https://guardian.ng/news/asuu-must-show-neutrality-in-sex-for -marks-scandals-aau-vc/. 